\title{
KAJIAN TENTANG PENDAPAT PELANGGAN PLN DI DESA PASSO DAN DESA RUMAH TIGA TERHADAP LISTRIK PRABAYAR DENGAN METODE ANALISIS VARIANSI
}

\author{
Mozart W. Talakua', H. Abrahams², Yopi Andry Lesnussa ${ }^{3}$ \\ 1,2,3 Jurusan Matematika Fakultas Matematika dan Ilmu Pengetahuan Alam,Universitas Pattimura \\ Jalan Ir. M. Putuhena, Kampus Unpatti, Poka, Ambon, Indonesia Ir.M.Putuhena, Ambon \\ e-mail: ${ }^{1}$ ocat_14@yahoo.com; ${ }^{2}$ r.Henskifranski@gmail.com; ${ }^{3}$ ya.lesnussa@fmipa.unpatti.ac.id
}

\begin{abstract}
Abstrak
Listrik prabayar adalah inovasi terbaru dari layanan PLN. Pada sistem listrik prabayar, pelanggan mengeluarkan biaya awal untuk membeli energi listrik yang akan dikonsumsinya sehingga bisa mengendalikan sendiri penggunaan listrik sesuai kebutuhan dan kemampuan pelanggan. Permasalahan yang ingin dikaji adalah apakah terdapat perbedaan pendapat masyarakat terhadap listrik prabayar. Penelitian ini diarahkan untuk menganalisis pendapat pelanggan PLN yang berada di Desa Passo dan Desa Rumah Tiga. Metode yang digunakan dalam penelitian ini adalah Analisis Variansi. Data yang digunakan dalam penelitian merupakan data primer dengan jumlah sampel yang diambil adalah 100 yang terdiri dari 50 responden di Desa Passo dan 50 responden Desa Rumah Tiga. Hasil penelitian menunjukkan bahwa untuk Desa Passo probabilitas hitung yaitu > 0,05 maka $H_{0}$ di terima. Artinya tidak terdapat perbedaan rata-rata pendapat masyarakat Desa Passo terhadap listrik prabayar terhadap faktor kebebasan, faktor kemudahan, faktor sosialisasi, faktor harga, dan faktor kenyamanan, dan untuk Desa Rumah Tiga probabilitas hitung yaitu > 0,05 maka $H_{0}$ di terima. Artinya tidak terdapat perbedaan rata-rata pendapat masyarakat Desa Passo terhadap listrik prabayar terhadap faktor kebebasan, faktor kemudahan, faktor sosialisasi, faktor harga, dan faktor kenyamanan.
\end{abstract}

Kata kunci: Listrik Prabayar, Analisis Variansi.

\section{A STUDY ABOUT OPTIONS OF PLN CUSTOMERS IN PASSO VILLAGE AND RUMAH TIGA VILLAGE ON ELECTRICAL PREPAID WITH VARIANCE ANALYSIS METHOD}

\begin{abstract}
Prepaid electricity is the latest innovation of PLN service. In a prepaid electricity system, customers pay an initial fee to purchase electrical energy to be consumed so that they can control their own electricity usage according to customer needs and capabilities. The problem to be studied is whether there are differences of public opinion on prepaid electricity. This research is directed to analyze the opinion of PLN customers located in Passo Village and Rumah Tiga Village. The method used in this research is Variance Analysis. The data used in the study is the primary data with the number of samples taken is 100 consisting of 50 respondents in Passo village and 50 respondents of Rumah Tiga Village. The results showed that for Passo Village the probability of count is $>0.05$ then $H_{0}$ is received. This means that there is no difference in the average opinion of Passo villagers towards prepaid electricity on freedom factor, convenience factor, socialization factor, price factor, and comfort factor, and for Desa Rumah Tiga probability count is > 0,05 then $H_{0}$ is received. This means that there is no difference in the average opinion of Passo villagers towards prepaid electricity on freedom factor, convenience factor, socialization factor, price factor, and comfort factor.
\end{abstract}

Keywords : Prepaid Electricity, Variance Analysis. 


\section{Pendahuluan}

Selama ini pelanggan PLN mendapat layanan listrik paskabayar, yaitu pelanggan menggunakan energi listrik dulu dan membayar belakangan pada bulan berikutnya. Setiap bulan harus dicatat meter paskabayar, menghitung dan menerbitkan rekening yang harus dibayar pelanggan, melakukan penagihan kepada pelanggan yang terlambat atau tidak membayar, dan memutus aliran listrik jika pelanggan terlambat atau tidak membayar rekening listrik setelah waktu tertentu.

Inilah inovasi terkini dari layanan PLN yang lebih menjanjikan kemudahan, kebebasan dan kenyamanan bagi pelanggannya. Listrik pintar solusi isi ulang dari PLN [1]. Dengan listrik pintar, setiap pelanggan bisa mengendalikan sendiri penggunaan listriknya sesuai kebutuhan dan kemampuannya.

Permasalahan yang akan dikaji adalah penulis ingin melihat apakah ada perbedaan pendapat masyarakat di Desa Passo terhadap listrik prabayar dan di Desa Rumah Tiga terhadap listrik prabayar dengan faktor kebebasan, faktor kemudahan, faktor kenyamanan, faktor sosialisasi dan faktor harga. Penulis menggunakan metode analisis variansi. Alasan menggunakan metode ini karena permasalahan yang dihadapi oleh penulis ingin mengetahui apakah ada perbedan ratarata dari faktor-faktor tersebut terhadap pendapat masyarakat pengguna listrik prabayar.

\section{Tinjauan Pustaka}

Analisis varians (analysis of variance, ANOVA) adalah suatu metode analisis statistika yang termasuk ke dalam cabang statistika inferensi. Ia merupakan pengembangan dari masalah Behrens-Fisher, sehingga uji-F juga dipakai dalam pengambilan keputusan. Analisis varians pertama kali diperkenalkan oleh Sir Ronald Fisher, bapak statistika modern. Dalam praktik, analisis varians dapat merupakan uji hipotesis (lebih sering dipakai) maupun pendugaan (estimasi), khususnya di bidang genetika terapan). Supaya sahih (valid) dalam menafsirkan hasilnya, analisis varians menggantungkan diri pada empat asumsi yang harus dipenuhi dalam perancangan percobaan yaitu : Data berdistribusi normal, Varians atau ragamnya homogen, Masingmasing contoh saling bebas, Komponen-komponen dalam modelnya bersifat aditif (saling menjumlah) [12].

Sesuai dengan banyaknya faktor yang terlibat, maka Anova dibedakan secara garis besar menjadi dua yaitu : Anova tunggal atau anova satu arah, Anova ganda atau anova lebih dari satu arah. Yang dimaksud dengan analisis varians satu jalur adalah analisis varians yang digunakan untuk mengolah data yang hanya mengenal satu variabel pembanding. Dinamakan analisis varians satu arah, karena analisisnya menggunakan varians dan data hasil pengamatan merupakan pengaruh satu faktor [7].

Untuk mengetahui atau mengidentifikasi adanya dua faktor yang mungkin menyebabkan perbedaan dalam variabel terikat (dependent variable), digunakan variansi dua arah (two-way ANOVA) untuk mengukur setiap kombinasi dua faktor dari variabel terikat (dependent variable) yang sedang dikaji. Tujuan dari analisis dua-faktor adalah untuk mengestimasi dan membandingkan pengaruh dari perbandingan perlakuan yang berbeda-beda terhadap variabel bebas atau variabel respon. Anova dua-arah atau dua-faktor harus memenuhi asumsi-asumsi berikut yaitu : melakukan suatu eksperimen faktorial lengkap seimbang (balanced complete factorial experiment), menerapkan rancangan eksperimen acak lengkap (complete randomized experimental design). Sampel acak bebas dari unit eksperimen dikaitkan pada perlakuan (treatment), dan populasi dari semua nilai yang memungkinkan dari variabel respons berkaitan dengan semua perlakuan terdistribusi yang secara normal semua populasi tersebut memiliki varians yang sama [6].

\subsection{Faktor-faktor yang mempengaruhi pendapat pelanggan PLN pengguna listrik prabayar}

\section{A. Faktor kebebasan}

Kebebasan yang di maksud dalam penelitian ini adalah kebebasan pelanggan dalam menentukan besarnya pemakaian yang dapat digunakannya. 
B. Faktor kemudahan

Kemudahan yang dimaksud dalam penelitian ini adalah bagaimana pelanggan tersebut dalam mendapatkan token listrik (pulsa) listrik prabayar. Apakah PLN sudah menawarkan cara yang mudah bagi pelanggan atau mempersulit proses mendapatkan pulsa listrik tersebut.

C. Faktor kenyamanan

Kenyamanan juga mempengaruhi pendapat pelanggan dalam menngguakan listrik prabayar. Kenyamanan dalam ini adalah bagaimana tingkat kenyamanan mereka dalam menggunakan listrik prabayar.

D. Faktor sosialisasi

Sosialisasi yang di maksud dalam peneliti ini adalah menyangkut pemahaman masyarakat tentang listrik prabayar.

E. Faktor harga

Biaya Pemakaian yang akan diteliti adalah bagaimana pendapat pelanggan listrik prabayar dalam hal biaya pemakaian perbulan, apakah dengan adanya inovasi ini mereka terbebani karna menggunakan listrik semakin boros atau bahkan semakin hemat. Pendapat tentang biaya pemakain tersebut akan mempengaruhi merekan dalam memberi penilaian terhadap inovasi listrik prabayar.

\subsection{Penarikan Sampel}

Sampel adalah bagian dari populasi yang digunakan untuk menyimpulkan atau menggambarkan populasi. Pemilihan sampel dengan metode yang tepat dapat menggambarkan kondisi populasi sesungguhnya yang akurat. Secara umum, terdapat dua pendekatan dalam metode pemilihan sampel yaitu probability sampling dan nonprobability sampling. Dalam metode probability sampling, seluruh unsur (misalnya: orang, rumah tangga) dalam suatu populasi memiliki kesempatan yang sama untuk dipilih dalam sampel. Dalam metode ini, cara pemilihan sampel harus dilakukan secara acak (random). Demikian pula dengan jumlah sampel minimum, harus dihitung secara matematis berdasarkan probabilitas. Sebaliknya, dalam metode nonprobability sampling, unsur populasi yang dipilih sebagai sampel tidak memiliki kesempatan yang sama, misalnya karena ketersediaan (contoh: orang yang sukarela sebagai responden), atau karena dipilih peneliti secara subjektif. Sebagai akibatnya, penelitian tersebut tidak dapat menggambarkan kondisi populasi yang sesungguhnya.

Agar sampel yang kita ambil dapat benar-benar mewakili populasinya, kita perlu suatu standar ataupun cara dalam menentukan jumlah sampel. Ada beberapa metode yang digunakan untuk menentukan jumlah sampel salah satunya adalah metode slovin. Metode solvin digunakan untuk menentukan jumlah sampel yang akan diambil dari suatu populasi yang diketahui jumlahnya (Sastrosupadi, 2000). Secara matematis rumus solvin adalah sebagai berikut:

$$
n=\frac{N}{N \cdot e^{2}+1}
$$

Dengan:

$n=$ jumlah sampel

$N=$ jumlah populasi

$e=$ galat pendugaan

\subsection{Analisis Variansi}

Analisis variansi (ANOVA) adalah salah satu metode untuk menguji hipotesis kesamaan rata-rata dari tiga atau lebih populasi. Analisis variansi pertama kali diperkenalkan oleh Sir Ronald Fisher [5]. Tujuan dari analisis variansi untuk menguji apakah terdapat perbedaan yang signifikan antara rata-rata beberapa kelompok populasi (lebih dari dua), melalui ukuran-ukuran penyebaran (variansi) dari masing-masing kelompok populasi tersebut. Ada 3 asumsi yang mendasari analisis variansi , sebagai berikut : 
1. Populasi-populasi yang diteliti memiliki distribusi normal.

Suatu data membentuk distribusi normal jika jumlah data di atas dan di bawah mean adalah sama. Distribusi normal berupa kurva berbentuk lonceng setangkup yang melebar tak berhingga pada kedua arah positif dan negatifnya.

2. Populasi-populasi tersebut memiliki standar deviasi yang sama (atau variansi yang sama).

Varian dan Standar deviasi (simpangan baku) adalah ukuran-ukuran keragaman (variasi) data statistik yang paling sering digunakan. standar deviasi (simpangan baku) merupakan akar kuadrat dari varian. Oleh karena itu, jika salah satu nilai dari kedua ukuran tersebut diketahui maka akan diketahui juga nilai ukuran yang lain.

3. Sampel yang diambil dari populasi tersebut bersifat bebas, dan sampel diambil secara acak.

Sampel acak atau random sederhana adalah pengambilan sebuah sampel yang dilakukan dengan cara sedemikian rupa sehingga setiap individu yang di dalamnya mempunyai kesempatan yang sama untuk di jadikan sampel (probability sampling).

Hipotesis dalam analisis variansi (ANOVA) sebagai berikut :

$H_{0}: \mu_{1}=\mu_{2}=\mu_{3}=\cdots=\mu_{k}$, tidak ada perbedaan yang nyata antara rata-rata hitung dari $k$ kelompok.

$H_{1}: \mu_{1} \neq \mu_{2} \neq \mu_{3} \neq \cdots \neq \mu_{k}$, ada perbedaan yang nyata antara rata-rata hitung dari $k$ kelompok

Dengan tabel analisis variansi (ANOVA), sebagai berikut :

Tabel 1. Analisis variansi

\begin{tabular}{|l|l|l|l|l|}
\hline $\begin{array}{c}\text { Sumber } \\
\text { variansi }\end{array}$ & $\begin{array}{c}\text { Derajat } \\
\text { bebas }\end{array}$ & $\begin{array}{c}\text { Jumlah } \\
\text { kuadrat }\end{array}$ & $\begin{array}{c}\text { Kuadrat } \\
\text { rata-rata }\end{array}$ & Statistik F \\
\hline Perlakuan & $k-1$ & $J K P$ & $K R P=J K P /(k-1)$ & $F=K R P / K R G$ \\
\hline Galat & $k(\mathrm{n}-1)$ & $J K G$ & $K R G=J K G /(k(n-1))$ & \\
\hline Total & $\mathrm{N} k-1$ & $J K T$ & & \\
\hline
\end{tabular}

Berdasarkan tabel 1 maka diperoleh rumus :

$$
\begin{gathered}
J K T=\sum_{i=1}^{k} \sum_{j=1}^{n} X_{i j}^{2}-\frac{T_{. .}^{2}}{n k} \\
J K P=\frac{\sum_{i=1}^{k} T_{i .}^{2}}{n}-\frac{T_{. .}^{2}}{n k} \\
J K G=J K T-J K P
\end{gathered}
$$

Dimana : JKT $=$ Jumlah kuadrat total

$$
\begin{aligned}
& \text { JKP = Jumlah kuadrat perlakuan } \\
& \text { JKG = Jumlah kuadrat galat } \\
& \text { KRP = Kuadrat rata-rata perlakuan } \\
& \text { KRG = Kuadrat rata-rata galat }
\end{aligned}
$$

Dengan daerah penolakan yaitu $H_{0}$ ditolak jika $F$ hitung $>F_{\alpha(k-1, k(n-1))}$.

Kelebihan analisis variansi jika dibandingkan dengan pengujian $t$ yang berdasarkan perbedaan antara dua rata-rata adalah pengujian $t$ hanya dapat menguji perbedaan antara rata-rata tersebut saja. Sehingga untuk lebih dari dua rata-rata (mean) kita harus melakukan pengujian terhadap masing-masing rata-rata dengan 
rata-rata lainnya. Meskipun hal tersebut menyebabkan meningkatnya tingkat kesalahan yang disebut kesalahan tingkat satu akan semakin berkurang.

Walaupun demikian analisis variansi memiliki kelemahan, yaitu apabila terdapat perbedaan antar kelompok yang dianalisis, maka letak perbedaannya tidak diketahui, apakah antara A dan B, B dan C, A dan $\mathrm{C}$ dan seterusnya. Selain itu analisis variansi memerlukan paling sedikit dua kali pengulangan, bahkan empat kali lebih baik. Semakin banyak pengulangan, kita semakin percaya bahwa informasi rata-rata benar-benar mencerminkan kenyataan. Untuk mendeteksi perbedaan antar kelompok, analisis variansi dapat dilanjutkan dengan Scheff's test, Duncan Multiple Range test, Tukey'stes, Student-Newman-Keul's test. Pengecekan melalui suatu pengujian $t$ untuk masing-masing variable kurang baik karena semakin sering dilakukan pengujian $t$ secara simultan, tingkat kepercayaan semakin menurun.

Sesuai dengan banyaknya faktor yang terlibat, maka analisis variansi (ANOVA) dibedakan secara garis besar menjadi dua yaitu :

1. Analisis variansi satu jalur.

Analisis variansi satu jalur adalah analisis variansi yang digunakan untuk mengolah data yang hanya mengenal satu variabel pembanding.

2. Analisis variansi dua jalur.

Analisis variansi dua jalur adalah analisis variansi yang digunakan untuk mengolah data dengan menggunakan dua variabel pembanding.

\subsection{Analisis Variansi $n$ Arah}

Analisis variansi $n$ arah atau yang sering disebut dengan ANOVA $n$-way adalah analisis variansi yang dipengaruhi oleh lebih dari dua variabel bebas terhadap variabel tak bebas. Kriteria hipotesis yang akan diuji yaitu :

Jika sig atau probabilitas hitung $\leq 0,05$ maka $H_{0}$ ditolak.

Jika sig atau probabilitas hitung $>0,05$ maka $H_{0}$ diterima.

1. Pengaruh utama

$H_{0}$ : Tidak ada pengaruh perbedaan rata-rata yang signifikan antara faktor A atau faktor B atau faktor C atau faktor D ataufaktor E terhadap pendapat pelanggan PLN.

$H_{1}$ : Ada pengaruh perbedaan rata-rata yang signifikan antara faktor A atau faktor B atau faktor $\mathrm{C}$ atau faktor D atau faktor E terhadap pendapat pelanggan PLN.

2. Pengaruh interaksi

$H_{0}$ : Tidak ada pengaruh perbedaan rata-rata yang signifikan terhadap pendapat pelanggan PLN.

$H_{1}$ : Ada pengaruh perbedaan rata-rata yang terhadap pendapat pelanggan PLN.

\section{Hasil dan Pembahasan}

\subsection{Uji Validitas dan Reliabilitas}

Validitas adalah ketepatan atau kecermatan suatu instrument dalam mengukur apa yang akan diukur. Uji Validitas dilakukan dengan cara mengkorelasikan masing-masing skor item dengan skor total. Item-item pertanyaan yang berkorelasi signifikan dengan skor total menunjukan item-item tersebut valid. Jika nilai pvalue kurang dari $\alpha$ maka item-item pertanyaan dikatakan valid.

Uji relibilitas digunakan untuk mengetahui konsistensi alat ukur, apakah alat pengukur yang digunakan dapat diandalkan dan tetap konsisten jika pengukuran tersebut diulang. Uji reliabilitas menggunakan metode Alpha (Cronbach's). Suatu kuesioner dikatakan reliabel jika nilai Alpha Cronbach's lebih dari 0,6. 


\subsubsection{Uji Validitas}

Pengujian validitas menggunakan rumus product moment dari paerson dengan menghitung korelasi antar masing-masing skor item pertanyaan tiap variabel dengan skor totalnya.jika skor item tersebut berkorelasi positif dengan skor total item dan lebih tinggi dari korelasi antar item berarti menunjukan kevalidan instrumen tersebut. Hipotesis yang digunakan yaitu :

$$
\begin{aligned}
& \mathrm{H}_{0} \text { : Item/Pertanyaan Tidak Valid } \\
& \mathrm{H}_{1} \text { : Item/Pertanyaan Valid }
\end{aligned}
$$

Dengan menggunakan software SPSS diperoleh hasil sebagai berikut:

Tabel 2. Hasil Pengujian Validitas di Desa Passo

\begin{tabular}{|c|c|c|c|}
\hline Item/Pertanyaan & P-Value & $\boldsymbol{\alpha}$ & Keterangan \\
\hline Item 1 & 0,000 & \multirow{5}{*}{} & Valid \\
\hline Item 2 & 0,000 & Valid \\
\hline Item 3 & 0,000 & Valid \\
\hline Item 4 & 0,000 & \multirow{5}{*}{0,05} & Valid \\
\hline Item 5 & 0,000 & Valid \\
\hline Item 6 & 0,004 & Valid \\
\hline Item 7 & 0,001 & Valid \\
\hline Item 8 & 0,000 & & Valid \\
\hline Item 9 & 0,000 & & Valid \\
\hline Item 10 & 0,000 & & Valid \\
\hline
\end{tabular}

Berdasarkan Tabel 2, terlihat bahwa dengan menggunakan $\alpha$ sebesar 5\% maka diperoleh semua item/pertanyaan memiliki nilai p-value lebih kecil dari 0,05 sehingga Tolak $\mathrm{H}_{0}$. Hal ini menunjukan bahwa semua item/pertanyaan di Desa Passo valid.

Tabel 3. Hasil Pengujian Validitas di Desa Rumah Tiga

\begin{tabular}{|c|c|c|c|}
\hline Item/Pertanyaan & P-Value & $\boldsymbol{\alpha}$ & Keterangan \\
\hline Item 1 & 0,000 & \multirow{5}{*}{} & Valid \\
\hline Item 2 & 0,000 & Valid \\
\hline Item 3 & 0,000 & Valid \\
\hline Item 4 & 0,000 & \multirow{5}{*}{0,05} & Valid \\
\hline Item 5 & 0,004 & Valid \\
\hline Item 6 & 0,020 & Valid \\
\hline Item 7 & 0,000 & & Valid \\
\hline Item 8 & 0,000 & & Valid \\
\hline Item 9 & 0,000 & & Valid \\
\hline Item 10 & 0,000 & & Valid \\
\hline
\end{tabular}

Berdasarkan Tabel 3 terlihat bahwa dengan menggunakan $\alpha$ sebesar 5\% maka diperoleh semua item/pertanyaan memiliki nilai p-value lebih kecil dari 0,05 sehingga Tolak $\mathrm{H}_{0}$. Hal ini menunjukan bahwa semua item/pertanyaan di Desa Rumah Tiga valid.

\subsubsection{Uji Reliabilitas}

Setelah dilkukan uji validitas, langkah selanjutnya adalah pengujian reliabilitas untuk mengetahui konsistensi atau kestabilan alat ukur. Pengujian reliabilitas dalam penelitian ini menggunakan koefisien Cronbach's Alpha. Hasil pengujian reliabilitas dengan menggunakan software SPSS adalah sebagai berikut: 
Tabel 4. Hasil Pengujian Reliabilitas

\begin{tabular}{|c|c|c|}
\hline Variabel & Alpha & Keterangan \\
\hline Desa Passo & 0,758 & Reliabel \\
\hline Desa Rumah Tiga & 0,739 & Reliabel \\
\hline
\end{tabular}

Berdasarkan Tabel 4, terlihat bahwa dari kedua Desa tersebut memiliki nilai koefisien Cronbach's Alpha untuk semua variabel lebih dari 0,6. Hal ini menunjukan bahawa kuisioner telah reliabel.

\subsection{Pengumpulan Dan Pengolahan Data}

\subsubsection{Analisis Variansi}

Selanjutnya akan diuji apakah apakah ada faktor-faktor yang mempengaruhi pendapat responden di desa passo dan rumah tiga menggunakan analisis variansi, dengan menggunakan hipotesis sebagai berikut:

$H_{0}$ : tidak terdapat perbedaan antara faktor-faktor yang mempengarui pendapat responden di Desa Passo dan Rumah Tiga.

$H_{1}$ : terdapat perbedaan antara faktor-faktor yang mempengarui pendapat responden di Desa Passo dan Rumah Tiga.

Hasil analisis dengan menggunakan analisis variansi ditampilkan pada Tabel 3.4 dan 3.5 tersebut digunakan untuk menguji apakah terdapat perbedaan faktor-faktor yang mempengarui pendapat responden di Desa Passo dan Rumah Tiga.

Tabel 5. Test Of Between-Subject Effects

\begin{tabular}{|c|c|c|c|c|c|}
\hline Source & Tipe III sum of squares & Df & Mean square & $F$ & Sig. \\
\hline Corrected model & $19,069^{\mathrm{a}}$ & 24 & 0,795 & 1,039 & 0,461 \\
\hline Intercept & 71,227 & 1 & 71,227 & 93,175 & 0,000 \\
\hline A & 1,722 & 3 & 0,574 & 0,751 & 0,532 \\
\hline B & 1,440 & 3 & 0,480 & 0,628 & 0,604 \\
\hline C & 2,012 & 2 & 1,006 & 1,326 & 0,288 \\
\hline D & 0,844 & 2 & 0,422 & 0,552 & 0,583 \\
\hline E & 1,707 & 2 & 0,853 & 1,116 & 0,343 \\
\hline A*B & 0,145 & 2 & 0,073 & 0,195 & 0,910 \\
\hline$A^{*} \mathrm{C}$ & 0,000 & 0 & & & \\
\hline $\mathrm{A}^{*} \mathrm{D}$ & 0,000 & 0 & & & \\
\hline $\mathrm{A} * \mathrm{E}$ & 0,000 & 1 & 0,000 & 0,000 & 1,000 \\
\hline $\mathrm{B}$ C & 0,000 & 0 & & & \\
\hline $\mathrm{B} * \mathrm{D}$ & 0,000 & 0 & & & \\
\hline $\mathrm{B} * \mathrm{E}$ & 2,359 & 1 & 2,359 & 3,087 & 0,091 \\
\hline
\end{tabular}

Berdasarkan Tabel 5 di peroleh:

Faktor kebebasan (A) memiliki p_value $=0,532>\alpha$ dengan keputusan yang di ambil adalah terima $H_{0}$ artinya tidak terdapat perbedaan antara pendapat masyarakat terhadap faktor kebebasan,

Faktor kemudahan (B) memiliki p_value $=0,604>\alpha$ dengan keputusan yang di ambil adalah terima $H_{0}$ artinya tidak terdapat perbedaan antara pendapat masyarakat terhadap faktor kemudahan, 
Faktor sosialisasi (C) memiliki p_value $=0,288>\alpha$ dengan keputusan yang di ambil adalah terima $H_{0}$ artinya tidak terdapat perbedaan antara pendapat masyarakat terhadap faktor sosialisasi,

Faktor harga (D) memiliki p_value $=0,583>\alpha$ dengan keputusan yang di ambil adalah terima $H_{0}$ artinya tidak terdapat perbedaan antara pendapat masyarakat terhadap faktor harga,

Faktor kenyamanan (E) memiliki p_value $=0,343>\alpha$ dengan keputusan yang di ambil adalah terima $H_{0}$ artinya tidak terdapat perbedaan antara pendapat masyarakat terhadap faktor kenyamanan,

Faktor kebebasan (A) dan faktor kemudahan (B) memiliki p_value $=0,910>\alpha$ dengan keputusan yang di ambil adalah terima $H_{0}$ artinya tidak terdapat perbedaan antara pendapat masyarakat terhadap faktor kebebasan dan faktor kemudahan, faktor kebebasan (A) dan faktor kenyamanan (D) memiliki p_value = $1,000>\alpha=0,05$ dengan keputusan yang di ambil adalah terima $H_{0}$ artinya tidak terdapat perbedaan antara pendapat masyarakat terhadap faktor kebebasan dan faktor kenyamanan, faktor kemudahan (B) dan faktor harga (D) memiliki p_value $=0,091>\alpha$ dengan keputusan yang di ambil adalah terima $H_{0}$ artinya tidak terdapat perbedaan antara pendapat masyarakat terhadap faktor kemudahan dan faktor kenyamanan. Sehingga dengan kata lain tidak terdapat perbedaan pendapat masyarakat pengguna listrik prabayar di Desa Passo.

Tabel 6. Test Of Between-Subject Effects

\begin{tabular}{|c|c|c|c|c|c|}
\hline Source & Tipe III sum of squares & Df & Mean square & $\boldsymbol{F}$ & Sig. \\
\hline Corrected model & $30,500^{\mathrm{a}}$ & 42 & 0,726 & 0,635 & 0,830 \\
\hline Intercept & 200,051 & 1 & 200,051 & 175,044 & 0,000 \\
\hline A & 0,970 & 3 & 0,323 & 0,283 & 0,836 \\
\hline B & 0,370 & 2 & 0,185 & 0,162 & 0,853 \\
\hline $\mathbf{C}$ & 1,423 & 2 & 0,712 & 0,623 & 0,564 \\
\hline $\mathbf{D}$ & 2,051 & 4 & 0,625 & 0,547 & 0,708 \\
\hline $\mathbf{E}$ & 2,675 & 4 & 0,669 & 0,585 & 0,684 \\
\hline $\mathbf{A}^{* \mathbf{B}}$ & 0,106 & 2 & 0,053 & 0,046 & 0,955 \\
\hline $\mathbf{A}^{*} \mathbf{C}$ & 000 & 0 & & & \\
\hline A*D $^{*}$ & 1,333 & 1 & 1,333 & 1,167 & 0,316 \\
\hline
\end{tabular}

Berdasarkan Tabel 6 di peroleh:

Faktor kebebasan (A) memiliki nilai p_value $=0,836>\alpha$ dengan keputusan yang di ambil adalah terima $H_{0}$ artinya tidak terdapat perbedaan antara pendapat masyarakat terhadap faktor kebebasan,

Faktor kemudahan (B) memiliki p_value $=0,853>\alpha$ dengan keputusan yang di ambil adalah terima $H_{0}$ artinya tidak terdapat perbedaan antara pendapat masyarakat terhadap faktor kemudahan,

Faktor sosialisasi (C) memiliki p_value $=0,564>\alpha$ dengan keputusan yang di ambil adalah terima $H_{0}$ artinya tidak terdapat perbedaan antara pendapat masyarakat terhadap faktor sosialisasi,

Faktor harga (D) memiliki p_value $=0,708>\alpha=$ dengan keputusan yang di ambil adalah terima $H_{0}$ artinya tidak terdapat perbedaan antara pendapat masyarakat terhadap faktor harga,

Faktor kenyamanan (E) memiliki p_value $=0,684>\alpha$ dengan keputusan yang di ambil adalah terima $H_{0}$ artinya tidak terdapat perbedaan antara pendapat masyarakat terhadap faktor kenyamanan,

Faktor kebebasan (A) dan faktor kemudahan (B) memiliki p_value $=0,955>\alpha$ dengan keputusan yang di ambil adalah terima $H_{0}$ artinya tidak terdapat perbedaan antara pendapat masyarakat terhadap faktor kebebasan dan faktor kemudahan, faktor kebebasan (A) dan faktor harga (D) memiliki p_value $=1,316>\alpha$ dengan keputusan yang di ambil adalah terima $H_{0}$ artinya tidak terdapat perbedaan antara pendapat masyarakat terhadap faktor kebebasan dan faktor kenyamanan. Sehingga dengan kata lain tidak terdapat perbedaan pendapat masyarakat pengguna listrik prabayar di Desa Rumah Tiga. 


\section{Kesimpulan}

Dari hasil analisa data dan pembahasan maka dapat disimpulkan bahwa faktor-faktor yang mempengaruhi pendapat responden Desa Passo di peroleh p-value $>\alpha=0,05$. Sehingga keputusan yang diambil adalah terima $H_{0}$ yang artinya tidak terdapat perbedaan pendapat di Desa Passo terhadap pengguna listrik prabayar dari faktor kebebasan, faktor kemudahan, faktor sosialisasi, faktor harga, dan faktor kenyamanan. Sedangkan pada Desa Rumah Tiga di peroleh p-value $>\alpha=0,05$. Sehingga keputusan yang diambil adalah terima $H_{0}$ yang artinya tidak terdapat perbedaan pendapat di Desa Rumah Tiga terhadap pengguna listrik prabayar dari faktor kebebasan, faktor kemudahan, faktor sosialisasi, faktor harga, dan faktor kenyamanan..

\section{Daftar Pustaka}

[1] Ismerisa., Pengaruh pelayanan terhadap kepuasan pelanggan, Skripsi Thesis. UIN Sunankalijaga, 2013.

[2] Kadir., Statistika Untuk Peneliti Ilmu-Ilmu Sosial, Jakarta: Rosemata Sampurna, 2010.

[3] Riduwan., Dasar-dasar Statistika. Bandung : Alfabeta, 2008.

[4] Sawono, Jonathan., Model-Model Linear dan Non Linear dalam IBM SPSS 21, Jakarta: PT Gramedia, 2012.

[5] Steel, Robert G. D. \&Torrie, James H., Prinsip dan Prosedur Statistika Jakarta: PT. Gramedia Pustaka Utama, 1993.

[6] Sudjana., Metoda Statistika. Bandung: Tarsito Bandung, 1996.

[7] Sugiharto., Bahan kuliah statistik 2 Analisis Variansi, 2009.

[8] Supranto, J. M. A., Analisis Multivariat Arti dan Interprestasi, Jakarta: Rineka Cipta, 2010.

[9] Syukran, M., Suatu kajian tentang pendapat pelanggan PLN terhadap listrik prabayar dengan metode analisis variansi, 2014.

[10] Taufiq, M., Skipsi matematika dan statistika, 2017.

[11] http://pln.co.id. Listrik untuk Kehidupan. [Diakses tanggal 7 juli 2017]

[12] http://wikipedia.co.id. Analisis Variansi. [Diakses tanggal 20 juni 2017]. 
